\title{
PEMANFAATAN TEPUNG MANURE HASIL DEGRADASI \\ LARVA LALAT HITAM (Hermetia Illucens L) TERHADAP PERFORMANS AYAM KAMPUNG FASE LAYER
}

\author{
Monalisa M Nangoy, Martina. E. R. Montong*, Wapsiaty Utiah, Mursye. N. Regar \\ Fakultas Peternakan Universitas Sam Ratulangi, Manado 95115
}

\begin{abstract}
ABSTRAK
Ayam kampung yang merupakan salah satu jenis ternak yang telah memasyarakat dan peternakannya sudah tersebar diseluruh pelosok Nusantara. Ayam kampung telah banyak diternakan untuk diambil telurnya. Telur ayam kampung memiliki kandungan gizi yang baik untuk manusia. Salah satu yang dapat dimanfaatkan sebagai bahan pakan dalam ransum ayam kampung yaitu dengan menggunakan tepung manure hasil degradasi larva lalat hitam (tepung MHD). Bahan pakan ini mengandung nilai gizi yang cukup baik untuk ternak ayam kampung. Dalam penelitian ini manure hasil degradasi larva lalat hitam diolah menjadi tepung dan ditambahkan kedalam ransum dengan tujuan untuk mengetahui konsumsi ransum, produksi telur dan konversi ransum ayam kampung. Materi yang digunakan dalam penelitian ini adalah 40 ekor ayam kampung betina umur 56 minggu, kandang yang digunakan dalam penelitian ini adalah kandang sistem baterai ukuran 50x50x75cm.Penempatan ayam kampung dalam setiap unit kandang dilakukan secara acak. Rancangan yang digunakan dalam penelitian ini adalah rancangan acak lengkap (RAL) dengan 4 perlakuan 5 ulangan. Analisis statistik dilakukan menurut prosedur Steel dan Torrie (1991). Tiap ulangan (percobaan) menggunakan ayam kampung umur 56 minggu dengan perlakuan ; R0 $=0 \%$
\end{abstract}

*Korepondensi (corresponding autor) Email: martinamontong@gmail.com tepung MHD : R1=5\% tepung MHD : R2= $10 \%$ tepung $\mathrm{MHD}: \mathrm{R} 3=15 \%$ tepung MHD. Variabel yang diukur adalah jumlah konsumsi ransum,produksi telur dan konversi ransum. Hasil penelitian yang diperoleh menunjukkan perlakuan memberikan pengaruh yang sangat nyata $(\mathrm{P}<0,01)$ terhadap konsumsi ransum, produksi telur dan konversi ransum tidak berbeda nyata $(\mathrm{P}>0,05)$. Dapat disimpulkan bahwa tepung MHD sampai level 15\% dapat digunakan dalam ransum ayam kampung.

Kata kunci : Ayam Kampung, Lalat hitam, Tepung MHD

\section{ABSTRACT}

\section{UTILIZATION OF MANURE} DEGRADED BY BLACKFLIES LARVAE (HERMETIA ILLUCENS L) ON THE PERFORMANCE OF LAYING NATIVE CHICKEN. Native chicken is one of the livestocks that have been widely used for source of protein. It has already been maintained everywhere in Indonesia. Native chickens is widely kept for eggs because it contains good nutrients for human beings. One of the source of rations for native chicken is manure flour from the degradation of the blackflies larvae (MHD flour). This feed material contains a good nutritional value for this chicken. In this study the results of the degradation of manure blackflies larvae processed into flour and added into the rations with the aim to know the consumption of rations, egg production and 
rations conversion of native chicken. 40 native chickens females aged 56 weeks had been used.Baterry system cages of $50 \times 50 \times 75 \mathrm{~cm}$ in size was used to kept the native chickes. Placement of chicken in each unit was done randomly. A randomized complete design (RAL) with 4 treatment and 5 replications was used as design methods (Steel and Torrie, 1991). Each replication using native chickens age 56 weeks with the following treatments: R0 $=0 \%$ flour MHD: R1 $=5 \%$ flour MHD: R2 $=10 \%$ flour MHD: R3 $=15 \%$ flour MHD. The variable measured is the sum of rations consumption, egg production and rations conversion. The results obtained showed that there was highly significant difference $(\mathrm{P}<0.01)$ between treatmentsandrations consumption, egg production, and there was no significant difference $(\mathrm{P}>0.05)$ between treatmens and rations conversion. It can be concluded that as much as $15 \%$ of the MHDcan be used in chicken rations.

Keywords: Native Chicken, Black Flies, MHD flour.

\section{PENDAHULUAN}

Ayam kampung merupakan ayam lokal di Indonesia yang kehidupannya sudah lekat dengan masyarakat. Penampilan ayam kampung sangat beragam, begitu pula sifat genetiknya, penyebarannya sangat luas karena populasi ayam kampung dijumpai di kota maupun desa. Pemberian pakan pada ayam kampung dapat diberikan dalam 4 periode, yaitu: periode starter, umur 1 hari -8 minggu; periode grower-1, umur $8-12$ minggu, periode grower-2, umur $12-18$ minggu, dan Periode layer, umur diatas 18 minggu.

Telur merupakan produk peternakan yang memberikan sumbangan besar bagi tercapainya kecukupan gizi masyarakat (Anggorodi, 1985). Sebutir telur mempunyai gizi yang cukup sempurna karena mengandung zat-zat gizi yang lengkap dan mudah dicerna. Dalam upaya peningkatan produksi telur, ternak unggas harus diberi pakan sesuai kebutuhan dan mengandung gizi sesuai rekomendasi. Produksi telur sangat erat kaitannya dengan konsumsi pakan, konversi pakan. Pemberian pakan yang baik tentunya akan berpengaruh terhadap produksi telur, konsumsi pakan, dan juga angka konversi dari pakan yang diberikan. Pakan dalam usaha peternakan unggas memiliki peranan pokok yang perlu mendapat perhatian selain bibit dan manajemen.

Hermetia illucens L (lalat hitam) adalah serupa dengan lalat umumnya. Black Soldier Fly berwarna hitam dan sebagian segmen basal abdomennya berwarna transparan (wasp waist) sehingga sekilas menyerupai abdomen lebah. Panjang lalat berkisar antara 15-20mm, memiliki sepasang sayap dan tidak memiliki alat penyengat, jika terbang berkelompok dan menimbulkaan suara yang bising (Wardhana, 2016). Berdasarkan jenis kelaminnya lalat betina umumnya memiliki daya tahan hidup yang lebih pendek 
dibandingkan dengan lalat jantan (Tomberlin, et al., 2009)

Tepung Manure Hasil Degradasi (MHD) merupakan salah satu bahan yang dapat dijadikan bahan pakan sumber protein. Penelitian Sakaria dan Wawo (2004) mendapatkan bahwa penggunaan kotoran (manure) ayam sebagai campuran pakan mencapai 5-10\%. Kotoran (manure) ayam yang digunakan adalah kotoran (manure) anak ayam (umur 1 hari -8 minggu) atau kotoran (manure) ayam dara (umur 9 minggu - 22 minggu), tidak menggunakan kotoran (manure) ayam dewasa atau kotoran (manure) yang mengandung limbah (serbuk gergaji atau sekam). Kotoran (manure) ayam dikeringkan, kemudian ditumbuk halus sampai jadi tepung kotoran (manure) ayam. Penggunaan kotoran (manure) ayam dalam hal ini hanya sebagai pengganti konsentrat atupun tepung ikan dan bekicot. Larva dari $H$. illucens merupakan salah satu alternatif pakan yang memenuhi persyaratan sebagai sumber protein makanan yang mengandung protein kasar lebih dari 19\%, digolongkan sebagai bahan makanan sumber protein. Dalam penelitian Manangkot (2014) manure yang didegradasi larva lalat hitam setelah menjadi tepung kandungan protein nya mencapai $51,15 \%$.
Pemanfaatan lalat rumah (Musca domestica) dalam managemen pengolahan manure juga dilaporkan memberikan hasil yang baik. Manure yang dibiodegradasi menggunakan lalat rumah tersebut menghasilkan penurunan akumulasi manure, manure menjadi berbentuk granul, dan pengurangan bau manure akibat penurunan nitrogen mencapai $20 \%$ (Tomiczek, 2006). Demikian juga pupa lalat rumah tersebut memiliki nilai protein tinggi mencapai 63\%, 9-15\% lemak, dan $30 \%$ materi kering.

Berdasarkan uraian diatas, telah dilakukan penelitian bertujuan untuk mengetahui pemanfaatan tepung MHD dalam ransum ayam kampung terhadap konsumsi pakan, produksi telur dan konversi pakan.

\section{MATERI DAN METODE PENELITIAN}

Materi yang digunakan dalam penelitian ini adalah ayam kampung fase layer berumur 56 minggu sebanyak 40 ekor. Kandang yang digunakan dalam penelitian ini adalah kandang baterai. Bahan pakan yang digunakan dalam penelitian ini adalah jagung, konsentrat, dan tepung MHD. Metode penelitian yang digunakan adalah rancangan acak lengkap dengan 4 perlakuan dan 5 ulangan. 
Jurnal Zootek (“Zootek” Journal) Vol. 37 No. 2 : 370 - 377 (Juli 2017) ISSN 0852 -2626

Tabel 1. Komposisi zat gizi Tepung MHD

\begin{tabular}{lc}
\hline Zat Gizi & Tepung MHD \\
\hline Protein & 51,15 \\
Lemak & 2,06 \\
Serat Kasar & 2,75 \\
Kalsium & 9,84 \\
Phospor & 3,20 \\
ME (Kkal) & 2940 \\
\hline
\end{tabular}

Ket : Hasil Analisa Manangkot (2014)

Tabel 2. Komposisi Ransum Percobaan

\begin{tabular}{lcccc}
\hline & \multicolumn{3}{c}{ Jumlah } \\
\cline { 2 - 5 } Bahan Makanan & R0 & R1 & R2 & R3 \\
& $\%$ & $\%$ & 60 & 60 \\
\hline Jagung & 60 & 60 & 30 & 25 \\
Konsentrat & 40 & 35 & 10 & 15 \\
Tepung MHD & 0 & 5 & 100 & 100 \\
\hline Total & 100 & 100 & & \\
\hline
\end{tabular}

Tabel 3. Komposisi zat-zat makanan ransum percobaan

\begin{tabular}{lcccc}
\hline \multirow{2}{*}{ Kandungan zat makanan } & \multicolumn{4}{c}{ Presentasi } \\
\cline { 2 - 5 } & R0 & R1 & R2 & R3 \\
& $\%$ & $\%$ & 19,26 & 20,07 \\
\hline Protein (\%) & 17,16 & 18,16 & 3,50 & 3,26 \\
Serat Kasar (\%) & 4,00 & 3,75 & 3,22 & 3,25 \\
Lemak (\%) & 3,14 & 3,18 & 4,60 & 4,50 \\
Ca (Kalsium) (\%) & 4,81 & 4,70 & 0,95 & 1,03 \\
P (Fosfor) (\%) & 0,78 & 0,87 & 2607 & 2705 \\
Energi (EM) Kkal/kg & 2410 & 2509 & &
\end{tabular}

Ket : Hasil Perhitungan komposisi zat-zat makanan. 


\section{Variabel yang diamati :}

1. Konsumsi Ransum : dihitung dengan cara menimbang sejumlah pakan yang diberikan (gram) dikurangi sejumlah pakan yang tersisa (gram) yang dilakukan setiap 24 jam sekali (Anggorodi, 1985).

2. Produksi Telur dihitung berdasarkan rumus (Sudrajat et al,2014) HDP $=\frac{\text { Jumlah Produksi Telur (butir) }}{\text { Jumlah ayam pada saat penelitian }} X 100$

3. Konversi ransum dihitung berdasarkan rumus (Olgun et al, 2009).

$\begin{array}{ll}\text { Konversi } & \text { Ransum } \\ = & \frac{\text { Total Konsumsi Pakan }(\mathrm{g})}{\text { Berat Telur }(\mathrm{g})}\end{array}$

\begin{abstract}
Analisis Data
Dihitung secara statistik dengan menggunakan analisis ragam rancangan acak lengkap (RAL). Apabila terdapat perbedaan diantara perlakuan dilakukan uji lanjut BNJ (Beda Nyata Jujur) menurut Steel and Torrie (1994).
\end{abstract}

\section{HASIL DAN PEMBAHASAN}

\section{Pengaruh Perlakuan Terhadap Konsumsi Ransum}

Konsumsi pakan adalah banyaknya pakan yang diberikan dikurangi sisa pakan atau pakan yang menunjukkan rata- rata jumlah pakan yang dikonsumsi seekor ayam sesuai periode pemeliharaan (Scott $e t$ $a l .$, 1992). Hasil Konsumsi tertinggi hingga terendah yaitu R3: 105,22 ; R2: 104,83; R1: 103,99 ; R0: 103,89 gram/ekor/hari, Semakin tinggi level penggunaan MHD dalam ransum, semakin tinggi konsumsi ransum. Hasil analisis ragam konsumsi pakan menunjukan bahwa perlakuan berpengaruh sangat nyata $(\mathrm{P}<0,01)$ terhadap konsumsi ransum. Hasil penelitian Manangkot (2014) meningkatnya konsumsi ransum pada perlakuan R1, R2 dan R3 disebabkan karena ransum yang mengandung tepung MHD mempunyai bentuk partikel yang lebih halus sehingga lebih mudah dikonsumsi. Rataan konsumsi ransum berkisar antara 103,89 - 105,22 gram/ekor/hari. Perlakuan yang menggunakan tepung MHD dengan level 5 - $15 \%$ menunjukkan rataan konsumsi lebih tinggi dibandingkan dengan ransum kontrol. Hal ini menunjukkan bahwa penggunaan tepung MHD dalam ransum lebih disukai oleh ternak ayam kampung. Hasil penelitian Sulandari et al. (2007), bahwa ayam kampung yang dipelihara secara intensif mengkonsumsi ransum sebesar 80 - 100 gr/ekor/hari. Nuraini et al. (2012), menyatakan bahwa konsumsi pakan dipengaruhi oleh beberapa faktor antara lain : umur, kesehatan ternak, jenis ternak, aktivitas ternak, kuantitas dan kualitas ransum. 
Tabel. 4. Pengaruh perlakuan terhadap konsumsi ransum, produksi telur (HDP) dan konversi ransum

\begin{tabular}{cccc}
\hline Perlakuan & \multicolumn{3}{c}{ Variabel } \\
\cline { 2 - 4 } & $\begin{array}{c}\text { Konsumsi } \\
\text { ransum } \\
\text { (gram/ekor/hari) }\end{array}$ & $\begin{array}{c}\text { Produksi } \\
\text { Telur } \\
\text { HDP }(\%)\end{array}$ & $\begin{array}{c}\text { Konversi Ransum } \\
\text { (Konsumsi/HDP) }\end{array}$ \\
\hline R0 & $103,89^{\mathrm{a}}$ & 56,17 & 3,50 \\
R1 & $103,99^{\mathrm{a}}$ & 56,46 & 3,29 \\
R2 & $104,83^{\mathrm{abc}}$ & 58,09 & 3,26 \\
R3 & $105,22^{\mathrm{bc}}$ & 58,11 & 3,08 \\
\hline
\end{tabular}

Ket : Superskrip berbeda pada kolom yang sama artinya berbeda sangat nyata $(\mathrm{P}<0,01)$

\section{Pengaruh Perlakuan Terhadap Produksi Telur (HDP)}

Hasil analisis ragam menunjukkan bahwa pemberian tepung manure hasil degradasi larva lalat hitam pada ransum ayam kampung memberikan pengaruh yang tidak nyata $(\mathrm{P}>0,05)$ terhadap produksi telur. Rataan produksi telur ayam kampung berkisar antara 56,17 - 58,11\% (Tabel 4). Walaupun secara statistik tidak nyata namun produksi telur menunjukan peningkatan dari perlakuan R1, R2, dan R3. Hal ini disebabkan karena di dalam tepung MHD terdapat enzim- enzim salah satu enzim di dalamya adalah enzim protease (Manangkot 2014). Hal ini sejalan dengan yang dinyatakan oleh Anggorodi (1985) bahwa faktor makanan yang mempengaruhi produksi telur adalah kandungan protein dari makanan tersebut. Selain itu kemampuan ayam kampung dalam menghasilkan telur tergantung dari sistem pemeliharaannya, sistem pemeliharaan dari ekstensif menjadi semi intensif atau intensif dapat meningkatkan produktivitas ayam kampung (Sulandari et al., 2007). Selain itu, hal ini juga disebabkan karena adanya peningkatan konsumsi ransum. Produksi telur menunjukkan adanya peningkatan, hal ini sejalan dengan yang dikatakan oleh North and Bell (1990) yang menyatakan bahwa jumlah pakan yang dikonsumsi berpengaruh terhadap produksi ternak, dimana konsumsi pakan yang tinggi akan menghasilkan produksi yang tinggi pula.

\section{Pengaruh Perlakuan Terhadap Konversi Ransum}

Konversi ransum dapat digunakan sebagai gambaran koefisien produksi, dimana semakin kecil nilai konversi semakin efisien penggunaan ransum dan demikian sebaliknya. Hasil analisis ragam menunjukkan bahwa pemberian tepung manure hasil degradasi larva lalat hitam pada ayam kampung fase layer tidak 
memberikan pengaruh yang nyata $(\mathrm{P}>0,05)$ terhadap konversi ransum, hal ini menggambarkan bahwa pemanfaatan tepung MHD sampai dengan level $15 \%$ dalam ransum ayam kampung memberikan pengaruh yang sama terhadap konversi ransum. Rataan konversi ransum pada penelitian ini berkisar antara 3,08 sampai 3,50. Hasil penelitian Sulandari et al. (2007) terhadap ayam kampung yang dipelihara secara intensif konversi ransum sebesar 4,9 - 6,4. Hal ini menunjukkan penelitian menggunakan tepung MHD hasil konversi pakan lebih baik. Menurut Hurwits et al. (1998) bahwa nilai konversi pakan yang semakin kecil menandakan penggunaan pakan yang efisien.

\section{KESIMPULAN}

Berdasarkan hasil analisa dan pembahasan dapat disimpulkan bahwa penggunaan Tepung Manure Hasil Degradasi Larva Lalat Hitam sampai dengan $15 \%$ dapat digunakan dalam ransum ayam kampung fase layer karena dapat meningkatkan konsumsi ransum, produksi telur dan nilai konversi yang baik.

\section{DAFTAR PUSTAKA}

Anggorodi . R, 1985. Kemajuan Mutakhir Dalam Ilmu Makanan Ternak Unggas. Universitas Indonesia Press.
Hurwits, S., D. Sklan, H. Talpas and I. Plavnik. 1998. the efect of dietary protein level on the lysin and arginine requrements of growing chickens. J. Poult. Sci. 77: 698-696

Manangkot, H. J. 2014. Black soldier fly larva manure degradation as fish meal replacer in native chicken ration. Seria Zootehnie 62:139-142.

North, M. O. and D. D. Bell. 1990. Commercial Chicken Production Manual. The 4th Ed. Avi Publishing Company Inc. Westport, Connecticut.

Nuraini. S dan S. A. Latif. 2012.Fermented product by Monacus purpureus in poultry diet effects on laying performance and egg quality. Pakistan Journal Of Nutrition. 11: 507-510.

Olgun O. Y. Cufadar and A. O. Yildiz. 2009. Effect Of boron supplementaion feed with low calcium to diet on performance and egg quality in method laying hens, J. Anim. Vet adv. S(4).650-654 .

Sakaria, S dan B. Wawo. 2004. Penyusunan Ransum Ayam Buras Secara Sederhana. Hasil Penelitian (tidak dipublikasikan). Fakultas Peternakan Universitas Hasanudin.

Sulandari, S., M.S.A. Zein, S. Paryanti, T. Sartika. 2007. Sumberdaya Genetik Ayam Lokal Indonesia. Pusat Penelitian Biologi Lembaga Ilmu Pengetahuan Indonesia.

Sudrajat, D., D. Kardaya, E. Dihansih, S.F.S. Puteri.2014. Performa produksi telur burung puyuh yang diberikanransum mengandung kromium organik. JITV 19(14): 257-262 
Jurnal Zootek (“Zootek” Journal) Vol. 37 No. 2 : 370 - 377 (Juli 2017) ISSN 0852 -2626

Steel, R.G.D, and J.H Torrie, 1994. Prinsip dan Prosedur Statistika Suatu Pendidikan Geometrik, PT. Gramedia Pustaka Utama. Jakarta.

Tomberlin, J.K., P.H. Adler, H.M. Myers. 2009. Development of the Black Soldier Fly (Diptera: Stratiomyidae) in relation to temperature. Journal Environmental Entomol. 38: 930934
Tomiczek, M. 2006. Production methodologies of novel organic proteins: Insect and earthworms. Journal of Forensic Sciences 39(1): 215-222.

Wardhana, A. H. 2016. Black soldier fly (Hermetia illucens L) sebagai sumber protein alternatif pakan ternak. Journal Wartazoa 26(2): 069-078 